Therehave been frequent changes in the government in Bangladesh in the past. The opposition parties are making all efforts to pull down the govenment on the single issue of the Chittagong Hill Tracts Peace Accord.

In the final analysis, it can be said that a political settlement-within the framework of the Constitution of a country-can bring about a viable solution to a refugee problem which addresses the root causes of insurgency, and also takes into account the aspifations of ethnic minorities. Such political settlement brings about not only the repatriation of refugees living in othe countries but also ensures that future refugee outflow is very unlikely. Violations of human rights can be prevented only through such political settlements. The Chittagong Hill Tracts Peace Accord is in a way a model peace accord, which can be adopted in many refugee situations and also amongst inte mally-displaced persons.

\section{Notes}

1. A. S. Bhasin, Indo-Bangladesh Relations, 1971-1994, Vol. II, (New Delhi: Siba Exim Pvt. Ltd., 1996), 1151-1152.

2. Ibid., 1151-1152.

3. Ibid., 1160-1164.

4. Ibid., 1125.

5. Suhas Chakma, "Chittagong DeadlockThe Chakma Plight Remains Unsolved," Pioneer, 24 January 1994.

6. See Bhasin, Indo-Bangladesh Relations, 1971-1994, 1151.

7. Ibid., 1145 .

8. Ibid., 1179.

9. For the text of the Accord, see Annex.

10. Public Opinion Trends, New Delhi, 13 December 1997, 1237.

11. Public Opinion Trends, New Delhi,12March 1998, 247.

12. Ibid., 259.

13. Ibid., 407. 口

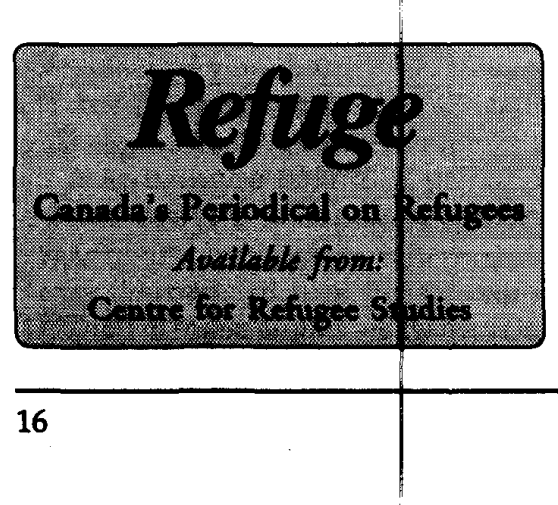

\title{
Annex: \\ Text of the Chittagong Hill Tracts Peace Treaty
}

Following is the English rendering of the peace agreementsigned between the National Committee on Chittagong Hill Tracts Affairs, formed by the Government of Bangladesh, and the Parbatya Chattagram Jana Sanghati Samity, reports Daily Star (3/12) quoting BSS.

(Text): Keeping full and unswerved allegiance in Bangladesh's state sovereignty and territorial integrity in Bangladesh's Chittagong Hill Tracts region under the jurisdiction of the Constitution of the People's Republic of Bangladesh, the National Committee on Chittagong Hill Tracts on behalf of the Government of People's Republic of Bangladesh and Parbatya Chattagram Jana Sanghati Samity on behalf of the inhabitants of Chittagong Hill Tracts reached the following agreement in four parts (namely: $\mathrm{Ka}, \mathrm{Kha}, \mathrm{Ga}, \mathrm{Gha}$ ) to uphold the political, social, cultural, educational and economic rights of all the people of Chittagong Hill Tracts region, expedite socio-economic development process and to preserve respective the rights of all the citizens of Bangladesh and their development.

\section{KA) General}

1. Both the sides recognised the need for protecting the characteristics and attaining overall development of the region considering Chittagong Hill Tracts as a tribal inhabited region.

2. Both the parties have decided to formulate, change, amend and incorporate concerned acts, regulations and practices as soon as possible in keeping with the consensus and responsibility expressed in different sections of the agreement.

3. Animplementation committee will be formed to monitor the implementation process of the agreement with the following members: Ka) amembernominated by the prime minister: Convenor,
Kha) a Chairman of the task force formed under the purview of the agreement... Member Ga) President of Parbatya Chattagram Jana Sanghati Samity....Member

4. The agreement will come into effect from the date of its signing and execution by both the sides. This agreement will be valid from the date of its effect until the steps are executed as per the agreement.

\section{KHA) Chittagong Hill Tracts Local Government Council/Hill District Council}

Both the sides have reached agreement with regard to changing, amending, incorporating and writing off the existing Parbatya Zila Sthanio Sarkar Parishad Ain 1989 (Rangamati Parbatya Zila Sthanio Sarkar Parishad Ain 1989, Bandarban Parbatya Zila Sthanio Sarkar Parishad 1989. Khagrachhari Parbalya Zila Sthanio Sarkar Parishad Ain 1989) and its different clauses before this agreement comes into force.

1. The word "tribal" used in different clauses of the Parishad Ain will stay.

2. The name Parbatya Zila Sthanio Sarkar Parishad will be amended and the name of Parishad will be "Parbatya Zila Parishad".

3. "Non-Tribal permanent residents" will mean those who are not tribals but have legal lands and generally live in hill districts at specific addresses.

4. Ka) There will be 3(three) seats for women in each of the Parbatya Zila Parishad. One-third $(1 / 3)$ of these seats will be for non-tribals.

Kha) 1,2,3 and 4 sub-clauses of clause 4 will remain in force as per the original act.

Ga) The words "Deputy Commissioner" and "Deputy Commissioner's" in the second line of Sub Clause (5) of 
Clause 4 will be replaced by "Circle Chief" and "Circle Chief's".

Gha) The following sub-clause will be incorporated in the Clause 4- "The concerned circle officer will ascertain whether a person is non-tribal or not on the basis of submission of certificate given by concerned mouza headman/ Union Parishad chairman/ pourashabha chairman and no nontribal person can become the non-tribal candidate without the certificate received from the circle officer regarding this."

5. In the Clause 7 it has been stated that the chairman or any other elected member will have to take oath or give declaration before Chittagong Divisional Commissionerbefore taking over office. Amending this in place of "Chittagong Division Commissioner" the members will take oath or give declaration before "any high court division judge."

6. The words "to Chittagong Divisional Commissioner" will be replaced by "as per election rules" in the fourth line of Clause 8.

7. The words "three years" will be replaced by "five years" in the second line of Clause 10.

8. In Clause Number 14 there will be provision that a tribal member elected by other members of the Parishad will chair and discharge other responsibilities if the post of chairman falls vacant or in his absence.

9. The existing Clause Number 17 will be replaced by the following sentences: a person will be considered eligible tobeenlisted in the voters listif he/ she (1) is a Bangladeshi citizen (2) he/ she is notbelow 18 years (3) appropriate court has not declared him mentally sick (4) he/she is a permanent resident of hill district.

10. In Sub-clause 2 of Clause Number 20 the words "delimitations of constituencies" will be incorporated independently.

11. In Sub-Clause 2 of Clause 25 there will be a provision that the chairman of all the meetings of the Parishad or a tribalmember elected by other members of the Parishad will chair meetings and discharge other responsibilities of the post of chairman falls vacant or in his absence.

12. As the entire region of Khagrachharidistrict is not included in the Mong circle, the words "Khagrachhari Mong Chief" in Clause Number 26 of Khagrachhari Parbatya Zila Sthanio Sarkar Parishad Ain will be replaced by the words "Mong Circle Chief and Chakma Circle Chief". Similarly, there will be scope for the presence of Bomang chief in the meeting of Rangamati Parbatya Zila Parishad. In the same way there willbe the provision that the Bomang Circle chief can attend the meetings of Bandarban Parbatya Zila Parishad meetings if he wishes or invited to join.

13. In Sub-Clause (1) and Sub-Clause (2) of Clause 31 there will be a provision that a chief executive officer of the status of a deputy secretary will be there as secretary in a Parishad and the tribal officials will get priority in this post.

14. Ka) In Sub-Clause (1) of Clause 32 there will be a provision that the Parishad will be able to createnew posts for different classes of officers and employees for properly conducting the activities of the Parishad.

Kha) The Sub-Clause 2 of Clause 32 will be amended as follows: the Parishad can according to rules recruit class three and four employees and can transfer, suspend, terminate or give any other punishment. Butcondition would be that in case of such appointments the tribal residents of the district will be given priority.

Ga) As per Sub-Clause (3) of Clause 32 , the government, in consultation with the Parishad, may appoint officers for the other posts and there will be legal provision to remove, suspend or terminate or penalise officers as per the government rules.

15. "As per rules" will be mentioned in Sub-Clause (3) of Rule 33.

16. In the third line of Sub-Clause (1) of Rule 36, the words "or in any way devised by the government" will be deleted.

17. Ka) The principal clause of the "fourth" of Sub-Clause (One) of Clause 37 will be valid.
Kha) "As per rules" will be included in Sub-Clause (2). Gha, of Rule 37.

18. Sub-Clause (3) of Clause 38, will be cancelled and Sub-Clause (4) will be amended in conformity with the follow text, "anewbudgetcan be prepared and approved. If needed, at any time, before the completion of the previous financial year."

19. Rule 42 will incorporate the following subclause:

"The Parishad, with the allocated money from the government, will receive, initiate or implement any development project in the transferred subjects and all national level development programmes will be implemented through the Parishad by the concerned ministries/divisions/organisations."

20. The word "Parishad" will replace the word "Government" in the second line of Sub-Clause (2) of Rule 45.

21. Rules 50, 51, and 52 will be repealed and following clauses will be introduced:

"If needed, the government will give advice or regulatory directives for streamlining the Parishad activities with the objectives of the aforesaid rules."

"The government, if the government receives any hard evidence that any activity or proposed activity of the Parishad is violating the aforesaid rules or is inconsistent with it, will have the authority to ask for written information along with explanation. The government willalso have the authority to give advice or directives in this regard."

22. "Within 90 days of abolition of the Parishad" shall be read in place of "after the expiry of defunct period" before the words "The Act" under Clause 53 Sub-Clause (3).

23. The word "Government" will be replaced by the word "Ministry" in the third and fourth lines in Clause 61.

24. A) Sub-Clause (1) in Clause 62 will be replaced by the following:

Whatever be the provisions in the currently prevailing laws, hill districts police sub-inspector and below shall be appointed by the Parishad as per the prescribed rules and the Parishad will transfer, and take action against them as per the prescribed rules. 
However the condition will be that tribals of the district will get preference in case of this appointment.

25. The words "supports will be provided" will remain in thind line in Clause 63.

26. Clause 64 will be amended as follows.

A) Whatever exists in the currently prevailing laws, without prior permission of the Parishad, no lands, including leasable khas lands in the district, can be leased out, sold, purchased or transferred.

However, it will not be ap licable in case of the reserved forest, Kaptai Hydroelectricity Project area, Betbunia Satellite Station area, state-owned industrial enterprises, and lands recorded in the name of the government.

B) Whatever exists in the currently prevailing other laws the government cannot acquire or transfer any lands, hills and forests under the jurisdictions of the hill district Parishad without prior discussion and approval of the Parishad.

Ga) The Parishad may supervise or control the work of headmen, chairman, amin, surveyors, kanungo and assistant commissioners (land).

Gha) The fringe land of Kaptai Lake will be leased out on priority basis to their original owners.

27. Clause 65 will be amended to formulate the following: For the time being, whatever law is in force/the land development tax of the district will be in the hand of the Parishad and the tax to be collected on that account will be in the fund of the Parishad.

28. Clause 67 will be amended to formulate the following: Parishad and the government will raise specific proposals if it is necessary for the coordination of the Parishad and the government, and coordination of work will be done through mutual consultations.

29. Sub-Clause (1) of Clause 68 will be amended to formulate the following sub-clause:

With a view to fulfilling the objectives of this law, the government will be able to prepare rules after discussion with the Parishad through gazettenotification. Even after the formulation of any rule, the Parishad will have the right to appeal to the government for reconsideration of such rules.

30. $\mathrm{Ka}$ ) In the first and second paragraphs of Sub-Clause (1) of Clause 69, the words "prior approval of the government" will be dropped and following part will be added after the words "should be done" in the third para:

It is conditional that if the government disagrees with any part of the provision formulated then the government will be able to provide suggestions or directives regarding the provision.

$\mathrm{Kha}$ ) in the (Ja) of Sub-Clause (2) of Clause 69, the other related laws, acts and ordinances and the Local Government Council Law of 1989, it will be settled as per the advice and the proposals of the regional council.

12) The government may form an interim regional council and give it the responsibilities of the council until and unless the regional council is formed on the basis of direct and indirect election.

13) The government may formulate any law regarding Chittagong Hill Tracts subject to discussion with the regional council and that will be done as per the advice of the council.

14) Fund of the council will be formed from the following sources:

a) Finance received from the district council fund.

b) Finance and profits from all the property which have been provided and directed by the council.

c) Loan and grants from the government and other authorities.

d) Grants provided by any institution or person.

e) Profit from the financial investment of the ouncil.

f) Any of the finance received by the council.

g) Finance received from other sources of income provided to the council as per the direction of the government.

\section{GHA) Rehabilitation, General Amnesty and Other Issues}

Both sides have reached the following position and agreed to take programmes for restoring normal situation in Chittagong Hill Tracts area and to this end on the matters of rehabilitation, general amnesty and other related issues and activities.

1) An agreement as signed between the government and the tribal refugee leaders on March 9,1997, at Agartala of TripuraState, on bringing back the tribal refugees staying in the State of Tripura. Under this agreement, repatriation of tribal refugees began on March 28, 1997. This process will continue and the leaders of the PCJSS will extend all possible cooperation in this regard. The internal refugees of the three hill districts will be rehabilitated through their properidentification by a task force.

2) The land record and right of possession of the tribal people will be ascertained after finalisation of the ownership of land of the tribal people. And to achieve this end, the government will start land survey in Chittagong Hill Tracts and resolve all disputes relating to land through proper scrutiny and verification in consultation with the regional council to be formed under this agreement. These steps will be taken soon after signing and implementation of this agreement between the government and the PCJSS and rehabilitation of the tribal refugees and internal tribal refugees.

3) The government will ensure leasing two acres of land in the respective locality subject to availability of land of the landless tribals or the tribals having less than two acres of land per family. However, groveland can be allotted in case of non-availability of necessary lands.

4) A commission (land commission) will be constituted under a retired judge for the disposal of all disputes relating to lands. Besides settlement of the land disputes of the rehabilitated tribals, this commission will have full power to annul all rights of ownership on land and hills which have so far been given illegal settlements or encroached illegally. No appeal can be made against the verdict of this commission and the decision of this commission will be treated as final. This will be implied in case of fringe land.

5) This commission will be constituted with the following members: 
Ka) Retiredjudge.

Kha) Circle chief (concerned).

$\mathrm{Ga}$ ) Chairman representative of the regional council.

Gha) Divisional commissioner/additional commissioner.

Uma) Chairman of the district council (concerned).

6) Ka) The tenure of the commission will be of three years. But the tenure can be extended in consultation with the regional council.

Kha) The commission will resolve disputes on the basis of existing laws, customs and systems of Chittagong Hill Tracts.

7) The loans, which were obtained by repatriated tribals from government agencies butcould not (be) properly utilised owing to conflicting situation, will be exempted with full interest.

8) Rubber plantation and allotment of other lands. The allotments of lands tonon-tribals and non-residents for rubber cultivation and other purposes but not yet utilised the lands for the projects properly during the last ten years, will be cancelled.

9) The government will allocate additional finance on priority basis for taking up maximum number of projects to develop Chittagong Hill Tracts. Projects will be implemented on priority basis for construction of infrastructure for the development of the region and the government will allocate necessary funds for this purpose. The government will encourage development of tourism for local and foreign tourists, taking into consideration the environmental aspect of the region.

10) Reservation of quota and allocation of scholarships: The government will continue the quota system for the tribals in case of government jobs and higher education till they reach at par with the people of other regions of the country. With this aim in views the government will provide more scholarships for tribals boys/girls in educational institutions. The government will provide necessary scholarships for taking education abroad and research pursuit.

11) The government and the elected representatives will be active topreserve the distinctiveness of the tribal culture and heritage. The government will provide due patronisation and assistance for expansion of tribal cultural activities at par with that of the mainstream of the national life.

12) The PCJSS will submit to the government within 45 days of signing of this agreement the full list of its armed members and description and accounts of all arms and weapons under its control and possession.

13) The government and the PCJSS will jointly decide the day, date and place for depositing arms by the PCJSS within 45 days of signing of this agreement The government will ensure all kinds of security for the members of the listed members of the PCJSS and their families for coming back to normal life after declaring the day, date and place for depositing arms by the listed members of the PCJSS.

14) The government will declare amnesty for those members who will deposit arms and ammunition on the scheduled date. The government will withdraw cases lodged earlier against those persons.

15) The government will take legal action against those who will not deposit arms and ammunition within the stipulated time.

16) General amnesty will be given to all PCJSS members after they return to normal life and this amnesty will also be given to all the permanent residents who were connected with the PCJSS activities.

$\mathrm{Ka}$ ) Each family of the repatriated members of the PCJSS will be given Taka 50,000 in cash at a time for their rehabilitation.

Kha) All cases, warrants of arrest, hulia againstany armed member or general member of the PCJSS will be withdrawn and punishment given after trial in absentia will be exempted after surrender of arms and coming back to normal life as soon as possible. The members of the PCJSS, if they are in jail, will be released.

$\mathrm{Ga}$ ) Similarly, no case will be filed or no punishment be given to any person for merely being the members of the
PCJSSafter surrendering arms and coming back to normal life.

Gha) The loans obtained by the members of the PCJSS from any government banks or other agencies but could notbe utilised owing to conflicting situation would beexempted with interest.

Uma) Those members of the PCJSS who wereemployed in various government jobs would be absorbed in their respective posts and the eligible members of their family will be given jobs as per their qualifications. In such cases, the government principles regarding relaxation of age will be followed.

Cha) Bank loans on soft term will be given to the members of the PCJSS for cottage industry and horticulture and other such self-employment generating activities.

Chha) Educational facilities will be provided for the children of the PCJSS and the certificates obtained from foreign board and educational institutions will be considered as valid.

17) Ka) Immediately with signing and executing the agreement between the government and the PCJSS and with the mempers of the PCJSS coming to normal llfe, all temporary camps of army, ansar and village defence force in Chittagong Hill Tracts excepting Bangladesh Rifles(BDR) and permanentcantonments (three in three district headquarters and in Alikadam, Ruma and Dighinala) will be gradually brought back to the permanent places and a deadline for this will be fixed. The members of the armed forces can be deployed under due rules and procedures in case of deterioration of law and order situation and in times of natural calamities or like other parts of the country under the control of the civil administration. The regional council may request the appropriate authorities for such help and assistance in case of such a necessity and in due time.

Kha) The lands to be abandoned by military or paramilitary camps and cantonments will be either returned to the original owners or to the hill district councils.

18) The permanent residents of Chittagong Hill Tracts with priority to 
the tribals will be given appointment to all categories of officers and employees of all government, semi-government, parishad and autonomous bodies of Chittagong Hill Tracts. In case of absence of eligible persons among the permanent residents of Chittagong Hill Tracts for particular posts, the government may give appointment on lien or for a definitive period such posts.

19) A ministry on Chittagong Hill Tracts Affairs will be set up appointing one minister from the tribals. The following advisor committee will be constituted to assist this ministry:

1) The Minister in charge of Chittagong Hill Tracts Affairs;

2) Chairman/representative, regional council;

3) Chairman/representative, Rangamati Hill Distric/ Council;

5) Chairman/representative, Bandarban Hill District|Council;

6) MP, Rangamati;

7) MP, Khagrachhari;

8) MP, Bandarban,;

9) Chakma Raja (King);

10) Bomang Raja;

11) Mong Raja; and

12) Three non-tribal members to be nominated by the government taking one permanentinontribal resident from each three hill districts.

This agreement is prepared in Bangla and completed and signed in Phaka on Agrahayan 18, 1404, December 2, 1997.
On behalf of

the Government of the People's Republic of Bangladesh (Abul Hasanat Abdullah)

Convener, NationalCommittee on Chittagong Hill Tracts, Government of Bangladesh (POT)
On behalf of the residents of Chittagong Hill Tracts Jyotírindra Bodhipriya Larma) President Parbatya Chattagram Jana Sanghati Samity

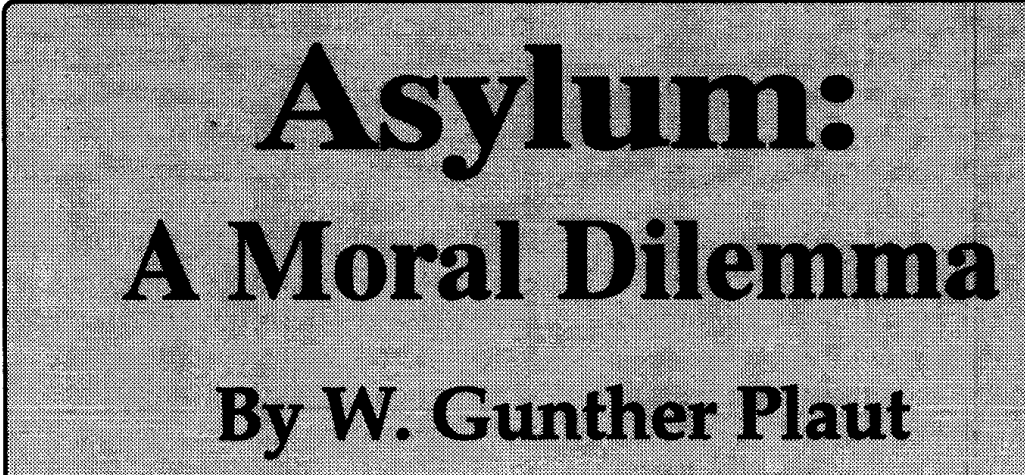

Toronto: York Lanes Press, 1995; ISBN 1-55014-239-9; 192 pages, indexed; $\$ 19.90$

Every year the refugee landscape changes, but only in that more problems are added, fewer are solved, and all become constantly more urgent. Fuelled by the explosion of the world's population, the quest for asylum is one of the most pressing problems of our age. Refugee-receiving nations-located frequently, but by no means exclusively, in the Western world-have to respond to masses of humanity searching for new livable homes. Human compassion for these refugees can be found everywhere, but so can xenophobia and the desire to preserve one's nation, economic well being, and cultural integrity. The clash between these impulses represents one of the great dilemmas of our time and is the subject of Plaut s study. In exploring it, he provides a far-ranging inquiry into the human condition.

The book presents political, ethnic, philosophical, religious, and sociological arguments, and deals with some of the most troublesome and heartbreaking conflicts in the news.

Contents: The Issues; Questions Without Answers; Definitions; Religion, Natural Law, and Hospitality, A Look at History; Some Ethical Questions; Through the Lens of Sociobiology; Community and Individual; Contended Rights: To Leave, Return, Remain.

The Practice; Refugees in Africa; Four Asian Lands; Glimpses of Europe and Central America; The North American Experience: The Sanctuary Movement; A Final Look; Bibliography; Index. Asylum-A Moral Dilemma is simultaneously published in the United States by Praeger Publishers, and in Canada by. York tanes Press:

\section{Available from:}

Centre for Refugee Studies, York University Suite 333, York Lines 4700 Keele Street, Toranto ON MBr.1P3

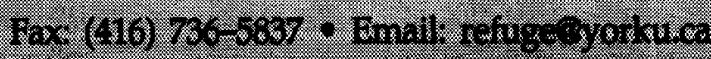

